\title{
REGULARARTICLE \\ PHYTOCHEMICAL SCREENING AND ANTIBACTERIAL ACTIVITY OF LANTANA CAMARA LEAVES AGAINST BACTERIA ISOLATED FROM EPICARP OF SOLANUM MELONGENA (GARDEN EGG)
}

\author{
M. M. SHAH* ${ }^{*}$ U. ABDULMUTALIB, K. M. IBRAHIM
}

Department of Biological Sciences, Faculty of Science, Yusuf Maitama Sule University, Kano State, Nigeria

\begin{abstract}
Certain plants and herbs with potencies in healing diseases are termed as medicinal or herbal plants, the efficiency they have in curing diseases are believed to be as a result of an active biochemical compounds present in known as phytochemicals, these bioactive compounds vary in compositions and types and are presence in a wide arrays of plants. This research was aimed at testing the antibacterial properties of Lantana camara plant leaves extracts against the bacteria isolated from the epicarp of an unwashed garden egg Solanum melongena fruit. Qualitative phytochemical screening of the plant leaves shows that the plant possesses Tannin, Saponin, Glycosides and Reducing sugar, while Anthraquinones, Alkaloid were absent in all the various extracts used. Three different types of bacteria were isolated from the epicarp of the unwashed fruit sample; they include Pseudomonas aeruginosa, Staphylococcus aureus and Streptococcus spp. The minimum inhibitory concentration of the leaf extracts on Pseudomonas aeruginosa were $12 \mathrm{mg} / \mathrm{ml}$ for the methanolic extract and $48 \mathrm{mg} / \mathrm{ml}$ for the ethanolic extract. The minimum inhibitory concentration on Streptococcus spp. was $8 \mathrm{mg} / \mathrm{ml}$ for the methanolic extract and $4 \mathrm{mg} / \mathrm{ml}$ for ethanolic extract, while the minimum inhibitory concentration on Staphylococcus aureus was $25 \mathrm{mg} / \mathrm{ml}$ for the methanolic extract and 7 $\mathrm{mg} / \mathrm{ml}$ for the ethanolic extract. Methanolic extracts have the highest activity on Staphylococcus aureus at $8 \mathrm{mg} / \mathrm{ml}$, followed by Pseudomonas aeruginosa at $12 \mathrm{mg} / \mathrm{ml}$ and the least was on Streptococcus spp. at $25 \mathrm{mg} / \mathrm{ml}$. While with ethanolic extracts, the highest activity was on Streptococcus spp. at $4 \mathrm{mg} / \mathrm{ml}$ followed by Staphylococcus aureus at $7 \mathrm{mg} / \mathrm{ml}$ and the least was on Pseudomonas aeruginosa at $48 \mathrm{mg} / \mathrm{ml}$. Therefore, Lantana camara leaves contain bioactive compounds believe to have a bactericidal effect at various concentrations species wise.
\end{abstract}

Keywords: Lantana camara, Solanum melongena, Epicarp, Bacteria, Phytochemicals

\section{INTRODUCTION}

Medicinal plants are those plants which have a potential to act on disease causing agents, or ameliorate disease agents and thus can be used for treating various ailments [1]. Many natural compounds have been isolated from plants and which made the basis of many drug inventions [2, 3]. Most of the modern medicines are derived from plant based compounds and secondary metabolites from plants [4]. Reports show that more than $80 \%$ of the population in Arab and African continents still depends on plant based medicines [5]. Consumption of fresh fruits and vegetables gives potential disease resisting capacity to human $[6,7]$.

Deterioration of foods generally is attributed to two main causes which are natural degradation due to activities of enzymes and growth of microorganisms (bacteria, molds and yeasts). These microorganisms can result in useful products through their activities particularly during fermentation of foods such as wine and cheese. The negative effects of these microbial activities result in decay, rotting of food and food poisoning, hence the basis of microbial food spoilage occurs when these microorganisms release their own enzymes into the foods and absorb the nutrients thereby changing the physical and chemical states of the foods thus lowering the nutritional value. Bacteria and fungi may also produce waste products which act as poisons or toxins, thus causing the renowned illeffects [6].

Pathogenic bacteria such as Streptococcus and Pseudomonas, cause many types of diseases in human and which are very difficult to treat or prevent [8].

Lantana camara is a shrub with flowers and strong shoot and well developed root system. The plant has been used in various purposes [9]. The present study aims to screen the phytochemicals and antibacterial activity of Lantana camara leaves against bacteria isolated from epicarp of Solanum melongena (garden egg).

Received 11 November 2017; Accepted 18 January 2018

${ }^{*}$ Corresponding Author

Shah M. M.

Department of Biological Sciences, Faculty of Science, Yusuf Maitama Sule University, Kano State, Nigeria

Email: mmanjurshah@gmail.com

(CThis article is open access and licensed under the terms of the Creative Commons Attribution License (http://creativecommons.org/licenses/by/4.o/) which permits unrestricted, use, distribution and reproduction in any medium, or format for any purpose, even commercially provided the work is properly cited. Attribution - You must give appropriate credit, provide a link to the license, and indicate if changes were made. 


\section{MATERIALS AND METHODS}

\section{Sample collection}

Fresh leaves of Lantana camara were collected on 9/8/2016 at Kano-Zoological and Botanical garden which was later identified and authenticated at the Department of Biological Sciences, Yusuf Maitama Sule University, Kano state, while the voucher specimens were preserved for future reference.

\section{Sample preparation}

The leaves were washed with water and dried under shade at room temperature for $7 \mathrm{~d}$. The dried leaves were pulverized with the aid of mortar and pestle, and packed in a clean dried container.

\section{Sample extraction}

The extraction was conducted according to the methods of Abdulmutalib and Shah, [10]. 6og of the dried pulverized leaves were weighed and suspended in a conical flask and soaked in $600 \mathrm{ml}$ of methanol and ethanol respectively as solvents for $72 \mathrm{~h}$ with a periodic shaking. The Soaked sample was then filtered using Whatman's no. 1 filter paper and the filtrate was collected and stored for analysis.

\section{Qualitative phytochemical screening}

The phytochemical screening was carried out based on the standard procedure [21].

\section{Bacterial isolation}

Bacterial was isolated by washing the garden egg Solanum melongena with $100 \mathrm{ml}$ of sterilized distilled water [11].

\section{Serial dilution}

$1 \mathrm{ml}$ of the stock solution was serially diluted as described previously [11].

\section{Media preparation}

The media (nutrient agar) was prepared according to the manufacturer's instruction and autoclaved at $121^{\circ} \mathrm{C}$ for 15 $\min$.

\section{Culturing}

The stock samples were inoculated on prepared Nutrient Agar media and incubated for $18-24 \mathrm{~h}$ at $37^{\circ} \mathrm{C}$. Growth was observed the following day as described earlier [12].

\section{Colony identification and counting}

Colonies grown were identified based on their morphological appearances like color, size, shape and elevation and were counted to the nearest CFU unit which were later sub-cultured [13].

\section{Gram staining}

Gram staining was carried out according to the procedure described earlier [14].

\section{Biochemical tests}

Bacterial isolates were biochemically screened by IMViC biochemical tests.

\section{Antibacterial sensitivity test}

Stock concentration of the extract was prepared by dissolving several concentration of the extract ( $25 \mathrm{mg}, 50$ $\mathrm{mg}, 75 \mathrm{mg}, 100 \mathrm{mg}$, and $125 \mathrm{mg}$ ) in $1 \mathrm{ml}$ of dimethyl sulfurdeoxide (DMSO).

\section{Sensitivity test}

Antibiotic sensitivity test was carried out according to Kirby Bauer's disc diffusion method [15].

Determination of minimum inhibitory
concentration (MIC)

The minimum inhibitory concentration test was carried out according to the standard method [15].

\section{RESULTS}

Qualitative phytochemical screening of the plant extract shows the presence of tannin, saponin, glycosides, reducing sugar, while Anthraquinones, alkaloid were absent in all extracts and in both the solvents (table 3.1). Saponin test shows the formation of foam that indicate the presence of saponin, alkaloid test shows red colour precipitate that indicates the presence of alkaloid, steroid was indicated by reddish brown colour, anthraquinone was absence with milkish precipitation, carbohydrates show yellow color precipitate that indicates the presence of carbohydrates.

The morphological appearances of isolated bacterial colonies were identified in which the sizes, shapes, elevation, pigmentation and appearances were identified (fig. 3.2), the isolated bacteria show different pigmentation on the media in which the staphylococcus shows yellow pigmentation, it's colony appears to be shiny with convex elevation. The second isolate was found to be greenish with convex elevation, and shiny in appearance which was assumed to be Pseudomonas aeruginosa, while the third isolate was found to show no pigmented coloration but with convex elevation and which was suspected to be Streptococcus spp. Grams staining result shows that, Pseudomonas aeruginosa was found to be gram negative, while the Staphylococcus aureus and Streptococcusspp. were found to be gram positive (table 3.2).

Biochemical tests resultconfirmed that, the isolated bacteria were Pseudomonas aeruginosa, Staphylococcusaureus, Streptococcus species in which Pseudomonas aeruginosa was found to be indole negative with no change of colour and as well methyl red test while Staphylococcusaureus was found to be coagulase positive and catalase positive but Streptococcus specie was found to be negative to both coagulase and catalase tests (table 3.3).

The results of antibacterial sensitivity tests against the isolated bacteria revealed that, methanolic extract at higher concentration of $(75 \mathrm{mg} / \mathrm{ml}, 100 \mathrm{mg} / \mathrm{ml}, 125$ $\mathrm{mg} / \mathrm{ml}$ ) have shown the highest activities on Pseudomonas aeruginosa with no activity recorded at $25 \mathrm{mg} / \mathrm{ml}$ and 50 $\mathrm{mg} / \mathrm{ml}$ (fig. 3.1). The zone of inhibition of Pseudomonas aeruginosa for the ethanolic extract was $6 \mathrm{~mm}$ at 25 $\mathrm{mg} / \mathrm{ml}$ and $12 \mathrm{~mm}$ at $125 \mathrm{mg} / \mathrm{ml}$ (table 3.4, fig. 3.2). Methanolic extract at all concentrations $(25 \mathrm{mg} / \mathrm{ml}, 50$ $\mathrm{mg} / \mathrm{ml}, 75 \mathrm{mg} / \mathrm{ml}, 100 \mathrm{mg} / \mathrm{ml}$ and $125 \mathrm{mg} / \mathrm{ml}$ ) were found to show excellent activities on Streptococcus spp. (fig. 3.3). The zones of inhibition on Streptococcus spp. for the ethanolic extract were $12 \mathrm{~mm}$ at $25 \mathrm{mg} / \mathrm{ml}$ and $17 \mathrm{~mm}$ at $125 \mathrm{mg} / \mathrm{ml}$ (table 3.5, fig. 3.4). Methanolic extract at all concentrations $(25 \mathrm{mg} / \mathrm{ml}, 50 \mathrm{mg} / \mathrm{ml}, 75 \mathrm{mg} / \mathrm{ml}, 100$ $\mathrm{mg} / \mathrm{ml}, 125 \mathrm{mg} / \mathrm{ml}$ ) were also found to show good activity on Staphylococcus aureus (fig. 3.5). The zones of inhibition on Staphylococcus aureus for the ethanolic extract were $8 \mathrm{~mm}$ at $25 \mathrm{mg} / \mathrm{ml}$ and $15 \mathrm{~mm}$ at $125 \mathrm{mg} / \mathrm{ml}$ (table 3.6, fig. 3.6). 
The minimum inhibitory concentrations of various extracts on the isolated bacteria were revealed. The minimum inhibitory concentration on Pseudomonas aeruginosa was $12 \mathrm{mg} / \mathrm{ml}$ for the methanolic extract and $48 \mathrm{mg} / \mathrm{ml}$ for the ethanolic extract. The minimum inhibitory concentrations on Streptococcus spp. were 8 $\mathrm{mg} / \mathrm{ml}$ for methanolic extract and $4 \mathrm{mg} / \mathrm{ml}$ for the ethanolic extract, while the minimum inhibitory concentrations on Staphylococcus aureus were $25 \mathrm{mg} / \mathrm{ml}$ for the methanolic extract and $7 \mathrm{mg} / \mathrm{ml}$ for ethanolic extract (table 3.7 and fig. $3.7,3.8$ ).
The overall minimum inhibitory concentrations of the two extracts on the isolated bacteria were that, the methanolic extract has the highest activity on Staphylococcus aureus at $8 \mathrm{mg} / \mathrm{ml}$, followed by Pseudomonas aeruginosa at12 $\mathrm{mg} / \mathrm{ml}$ and the least was on Streptococcus spp. at 25 $\mathrm{mg} / \mathrm{ml}$ (Figure3.7). With the ethanolic extract, the highest activity was on Streptococcus spp. at $4 \mathrm{mg} / \mathrm{ml}$ followed by Staphylococcus aureus at $7 \mathrm{mg} / \mathrm{ml}$ and the least was on Pseudomonas aeruginosa at $48 \mathrm{mg} / \mathrm{ml}$.

Table 3.1: Qualitative phytochemicals screening of Lantana camara leaves using methanol and ethanol as solvents

\begin{tabular}{llll}
\hline S. No. & Phytochemicals screened & Methanolic extract & Ethanolic extract \\
\hline 1 & Tannins & + & + \\
2 & Saponins & + & + \\
3 & Carbohydrates & + & + \\
4 & Reducing sugar & + & - \\
5 & Anthraquinones & - & + \\
6 & Glycosides & + & - \\
7 & Alkaloids & - & \\
\hline
\end{tabular}

Key: Presence: +Absence: -

Table 3.2: Result for Morphological appearance and gram staining of isolated bacterial colonies

\begin{tabular}{llllllll}
\hline S. No. & Size & Shape & Color & Appearance & Elevation & Gram staining & Inference \\
\hline 1 & $0.2-0.4 \mathrm{~mm}$ & Circular & Greenish & Shiny & Convex & - & Pseudomonas spp. \\
2 & $0.1-0.3 \mathrm{~mm}$ & Circular & Nill & Shiny & Convex & + & Streptococcus spp. \\
3 & $0.2-0.4 \mathrm{~mm}$ & Circular & Yellow & Shiny & Convex & + & Staphylococcus spp. \\
\hline
\end{tabular}

Table 3•3: Result for the biochemical characterization of bacterial isolates

\begin{tabular}{|c|c|c|c|c|c|}
\hline S. No. & Indole & Methyl red & Catalase & Coagulase & Inference \\
\hline 1 & - & - & & & Pseudomonas spp. \\
\hline 2 & & & - & - & Streptococcus spp. \\
\hline 3 & & & + & + & Staphylococcus spp. \\
\hline
\end{tabular}

Key: Positive: +Negative: -

Table 3.4: Result for the antibacterial sensitivity tests (Zones of Inhibitions on Pseudomonas aeruginosa)

\begin{tabular}{llll}
\hline $\begin{array}{l}\text { Methanolic extract } \\
(\mathbf{m g} / \mathbf{m l})\end{array}$ & Zone of inhibition (mm) & Ethanolic extract (mg/ml) & Zone of inhibition (mm) \\
\hline 25 & 0 & 25 & 6 \\
50 & 0 & 50 & 7 \\
75 & 8 & 75 & 9 \\
100 & 12 & 100 & 10 \\
125 & 16 & 125 & 12 \\
\hline
\end{tabular}

Table 3.5: Result for the antibacterial sensitivity test (Zones of Inhibitions on Streptococcus spp.)

\begin{tabular}{llll}
\hline Methanolic extract (mg/ml) & Zone of inhibition (mm) & Ethanolic extract (mg/ml) & $\begin{array}{l}\text { Zone of inhibition } \\
\text { (mm) }\end{array}$ \\
\hline 25 & & 25 & 12 \\
50 & 12 & 50 & 13 \\
75 & 13 & 75 & 13 \\
100 & 14 & 100 & 15 \\
125 & 15 & 125 & 17 \\
\hline
\end{tabular}


Table 3.6: Result for the antibacterial sensitivity test (Zones of Inhibitions on Staphylococcus aureus)

\begin{tabular}{llll}
\hline Methanolic extract (mg/ml) & Zone of inhibition (mm) & $\begin{array}{l}\text { Ethanolic extract } \\
\text { (mg/ml) }\end{array}$ & $\begin{array}{l}\text { Zone of inhibition } \\
\text { (mm) }\end{array}$ \\
\hline 25 & 6 & 25 & 8 \\
50 & 8 & 50 & 9 \\
75 & 9 & 75 & 11 \\
100 & 10 & 100 & 13 \\
125 & 13 & 125 & 15 \\
\hline
\end{tabular}

Table 3.7: Result for the minimum inhibitory concentrations of various extracts on the isolated bacteria

\begin{tabular}{lll}
\hline Organisms & $\begin{array}{l}\text { Methanolic extract } \mathbf{( m g / m l )} \\
\text { Minimum inhibitory conc. }\end{array}$ & $\begin{array}{l}\text { Ethanolic extract (mg/ml) } \\
\text { Minimum inhibitory conc. }\end{array}$ \\
\hline Pseudomonas aeruginosa & 12 & 48 \\
Staphylococcus aureus & 25 & 7 \\
Streptococcus spp. & 8 & 4 \\
\hline
\end{tabular}

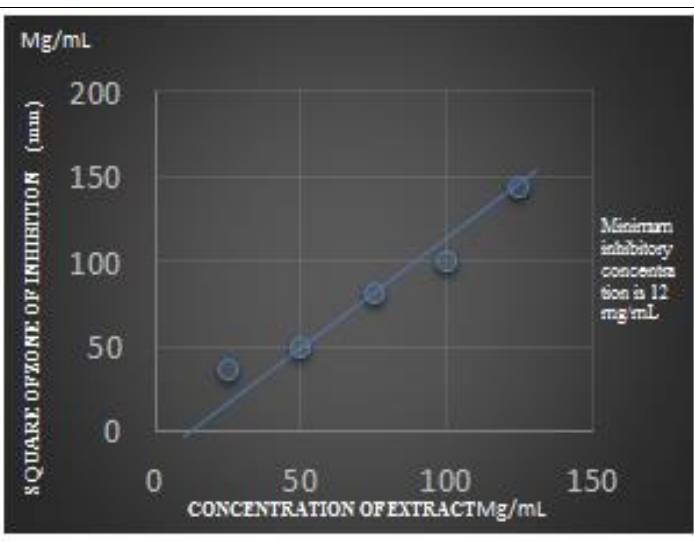

Fig. 3.1: Methanolic extract inhibition on $P$. aeruginosa

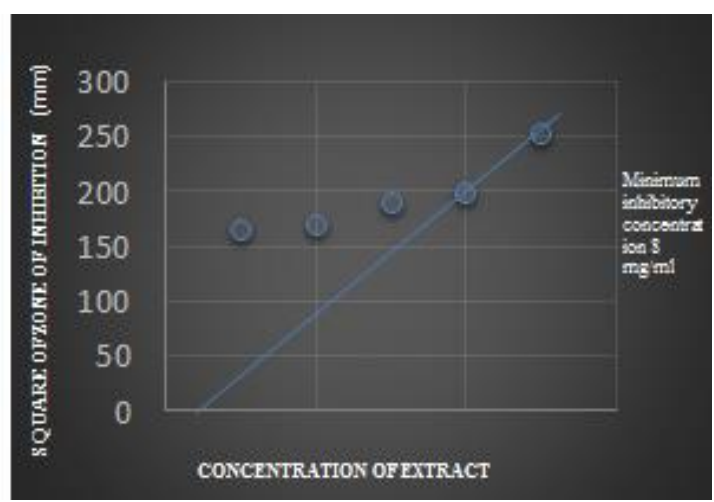

Fig. 3.3: Methanolic extract inhibition on Streptococcus spp

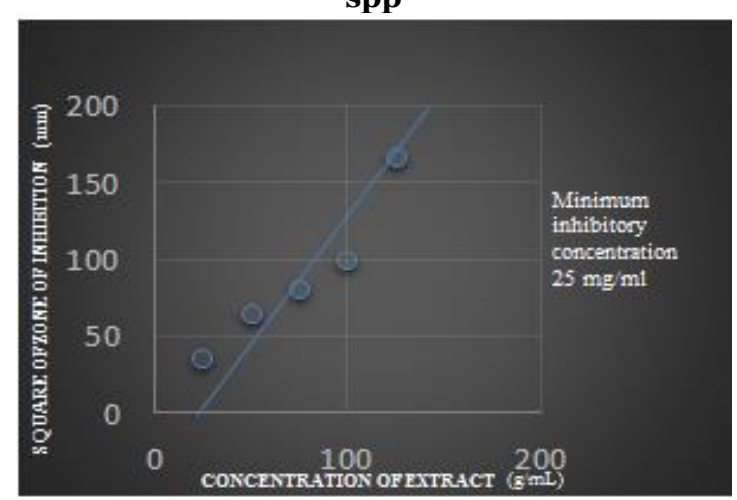

Fig. 3.5: Methanolic extract inhibition on Staphylococcus spp

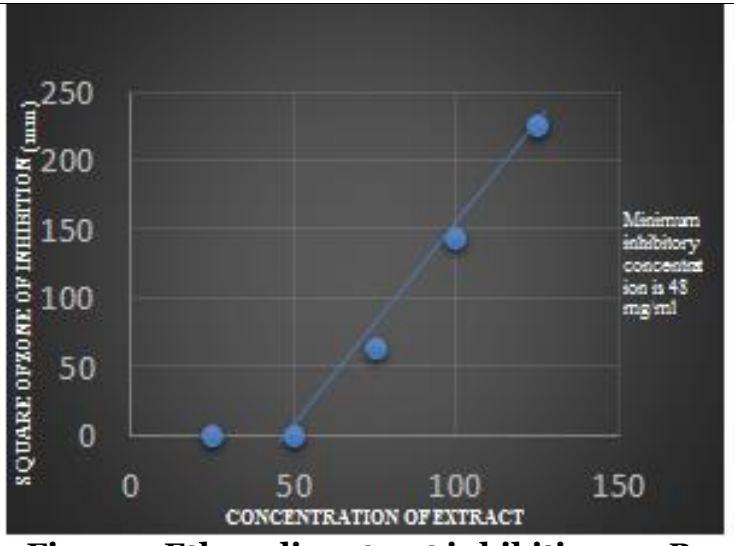

Fig. 3.2: Ethanolic extract inhibition on $P$. aeruginosa

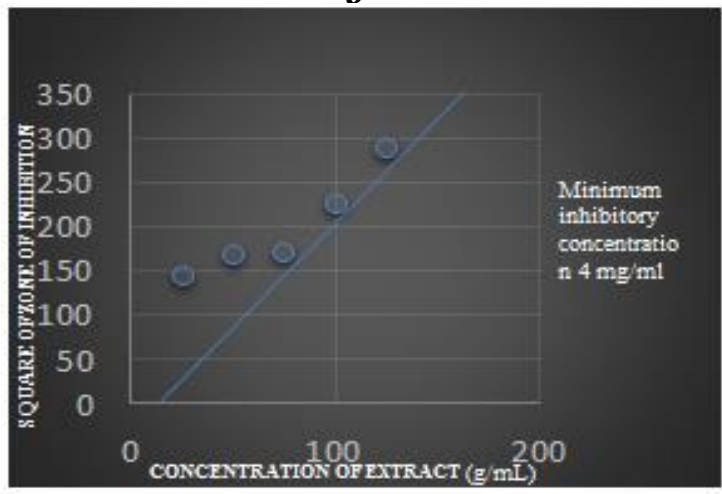

Fig. 3.4: Ethanolic extract inhibition on Streptococcus spp

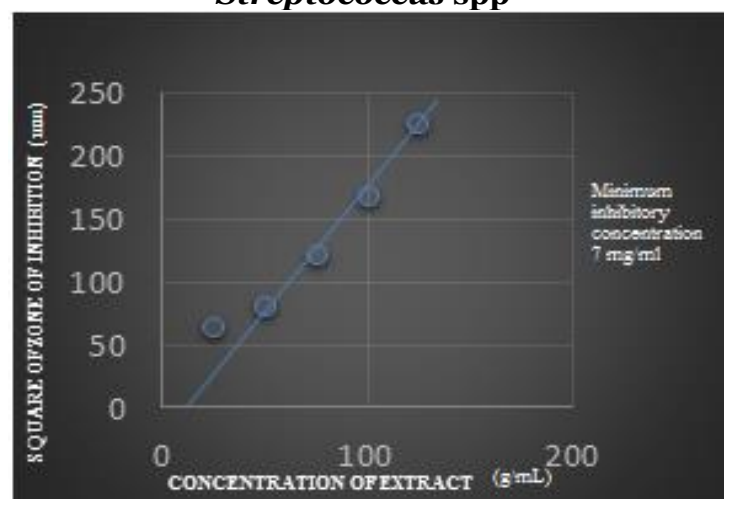

Fig. 3.6: Ethanolic extract inhibition on Staphylococcus spp 


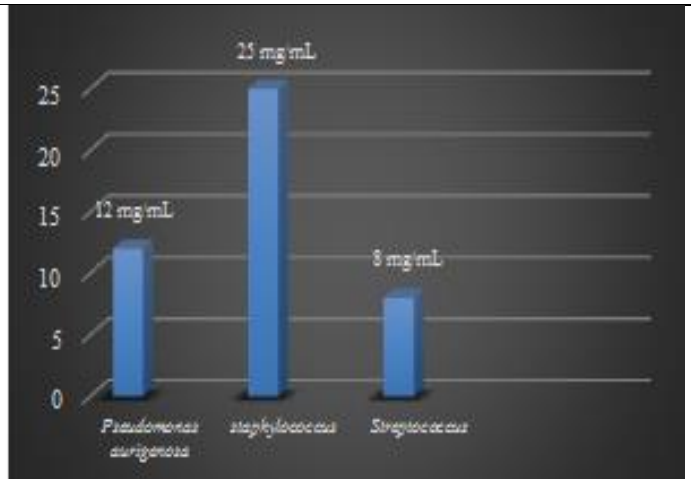

Fig. 3.7: MIC of methanolic extract of $L$. camara on bacterial isolates

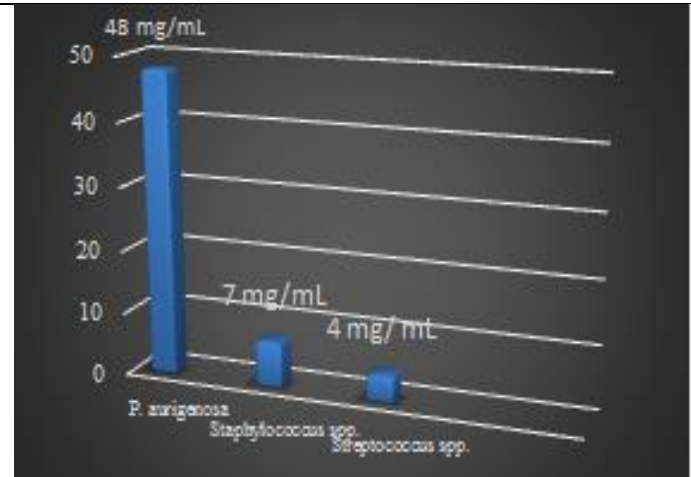

Fig. 3.8: MIC of ethanolic extract of L. camara on bacterial isolates

\section{DISCUSSION}

This research revealed the present of some secondary metabolites which is similar to the findings of Rabia et al. [16] in which the plant Lantana camara was found to possess same bioactive compounds phytochemicals.

This research also revealed that there are bacteria associated with the surface of unwashed garden egg. Among the bacteria isolated were Pseudomonas aeruginosa, Staphylococcus aureus and Streptococcus spp. the antibacterial activities of the extracts against these isolates vary with the solvents used during crude extracts extraction from the leaves and it also varies with the concentrations of the extracts in such a way that, the higher the concentration the higher the activities recorded. According to this research, the gram positive bacteria shows more activity with the extracts in which the minimum inhibitory concentrations of methanolic extract on the isolated bacteria was $8 \mathrm{mg} / \mathrm{ml}$ while that of ethanol was $4 \mathrm{mg} / \mathrm{ml}$. Our results are in agreement with previous reports [17-20].

\section{CONCLUSION}

Conclusively, From the Phytochemical screening of the leaves of Lantana camara, it was found that, tannins, saponins, reducing sugar, glycosides and carbohydrates were present in both the used solvents (methanol and ethanol) respectively. It can also be concluded that pathogenic bacteria can be found on an unwashed garden egg. After performing the antibacterial activity using Kirby Bauer disc diffusion method, it was found that both the extract has excellent antibacterial activities against all the isolated bacterial strains i.e. Pseudomonas aeruginosa, Streptococcus spp. and Staphylococcus aureus at various concentrations. The antibacterial activity of the leaf extracts may be due to the presence of various bioactive constituents in the leaves known as phytochemicals whilethe antibacterial bioactivity of the extract is more on Gram positive bacteria than the Gram negative ones.

\section{REFERENCES}

1. Joy, P. P., Thomas, S., Mathew, B. and Skaria. P. Medicinal Plants, Kerala Agricultural University, Aromatic and Medicinal Plants Research Station”. http://www. agr. gc. ca/eng/scienceandinnovation/science-publications-and resources/ resources/canadian-medicinal-crops/introductionto-medicinal-plants. 1998.
2. Tapsell, L. C., Hemphill, L. and Cobiac, L. Health Benefits of Herbs and Spices. International journal of health of medicine Department. 2006;185:4-24.

3. Lai, P. K. and Roy, J. Antimicrobial and Chemopreventive Properties of Herbs and Spices Research Journal of Recent Sciences 2004;3: 52-55.

4. Fabricant, D. S. and Farnsworth, N. R. The Value of Plants Used in Traditional Medicine for Drug Discovery. Farnsworth and company India. 2001;663: 69-75

5. WHO (2008). WHO Guidelines on safety monitoring of herbal medicines in Swizerland: world health organization.

6. Barth, M., Hankinson, T. R., Zhuang, H. and Breidt, F. Microbiological Spoilage of Fruits and Vegetables. Compendium of the Microbiological Spoilage of Foods and Beverages, Food Microbiology and Food Safety. Springer Science Business Media, LLC 2009:135-183.

7. Hung, H. C., Joshipura, K. J., Jiang, R. H., Hunter, D. Smith, S. "Fruits and Vegetable Intake and the Rrisk of Major Chronic Disease". Journal of National Cancer Institute. 2004;95:157-164.

8. Barrie, D. Contamination of Hospital linen by Bacillus cereus. Epidemiol Infection 1994;113: 297-306.

9. Sanjeeb, K., Gaurav, K., Loganathan, K. and Kokati, B. R. O. Phytochemical Composition and In vitro Hemolytic Activity of Lantana Camara L. (Verbenaceae) Leaves. Pharmacologyonline 2012;1:59-67.

10. Abdulmutalib, U. and Shah M. M. Phytochemical screening on the antioxidant properties of Aerva lanata flower extracts and their in vitro antiproliferative effects on human liver cancer cell line (hepg-2) running head-phytochemical screening of flower extracts of Aerva lanata. Journal of Biology and Nature 2017;7: 81-90.

11. Chand, S., Dubey, R. and Maheshwari, C. Practical Microbology, $3^{\text {rd }}$ edition. Chand,S. and Company Limited., Ram Nagar, New Delhi-110055. 2008 Pp. 21-38.

12. Elizabeth, K. T. Laboratory Manual of Microbiology for Biotechnology Students, Ane Books Pvt. Ltd. No. 4821, Parwana Bhawan, 24 Ansari Road, Darya Ganji, New Delhi-110002, India. 2011 Pp. 29-77.

13. John G. Holt, Noel R. Krieg, Peter H. A Sneath, James T. Staley and Stanley T. Williams. Bergey's Manual of Determinative Bacteriology, $9^{\text {th }}$ edition. Williams and Wilkins, 428 East Preston street, Baltimore, Maryland-20202, USA. 1994 Pp 27-74.

14. Cheesbrough, M. District laboratory practice in tropical countries, ${ }^{\text {nd }}$ edition. 2000 Pp. 46-67. 
15. Swamy P. M. Laboratory Manual on Biotechnology, $1^{\text {st }}$ edition. Rakesh Kumar Rastogi for Rastogi Publications, Gangotri Shivaji Road, Meerut-250 002 UP, India and Capital Offset Press New Delhi India. 2008 Pp. 237-238.

16. Rabia, N. and Asghari, B. Phytochemical screening, antioxidants and antimicrobial potential of Lantana camara in different solvents. Asian Pacific Journal of Tropical Disease, 2013;3: 480-486.

17. Glovannoni, S. J. and Rappe, M. S. The Uncultured Microbial Majority, Annual review of Microbiology 2003;57:369-94.

18. Ganjewala, D., Sam, S. and Khan, K. H. Biochemical Compositions and Antibacterial Activities of Lantana camara Plants with Yellow, Lavender, Red and White flowers. Eurasian Journal of Biological Sciences. 2009;2: 69-77.

19. Badakhshan, M. P. A Comparative Study: Antimicrobial Activity of Methanol Extracts of Lantana camara Various Parts". Pharmacognosy Research. 2009;1: 348-351.

20. Barreto, F. S. Antibacterial Activity of Lantana camara and Lantana montevidensis extracts from Cariri-Ceará”, Brazil. Journal of Young Pharmacists. 2010;2: 42-44.

21. Ghosal M, Mandal PA. Phytochemical screening and antioxidant activities of two selected 'bihi'fruits used as vegetables in Darjeeling Himalaya. International Journal of Pharmacy and Pharmaceutical Sciences. 2012;4:567-74. 